\title{
Short communication: Assessing antihypertensive activity in native and model Queso Fresco cheeses ${ }^{1}$
}

\author{
M. Paul ${ }^{2}$ and D. L. Van Hekken \\ Eastern Regional Research Center, Agricultural Research Service, US Department of Agriculture, 600 East Mermaid Lane, Wyndmoor, PA 19038
}

\begin{abstract}
Hispanic-style cheeses are one of the fastest growing varieties in the United States, making up approximately $2 \%$ of the total cheese production in this country. Queso Fresco is one of most popular Hispanicstyle cheeses. Protein extracts from several varieties of Mexican Queso Fresco and model Queso Fresco were analyzed for potential antihypertensive activity. Many Quesos Frescos obtained from Mexico are made from raw milk and therefore the native microflora is included in the cheese-making process. Model Queso Fresco samples were made from pasteurized milk and did not utilize starter cultures. Water-soluble protein extracts from 6 Mexican Quesos Frescos and 12 model cheeses were obtained and assayed for their ability to inhibit angiotensin-converting enzyme, implying potential as foods that can help to lower blood pressure. All model cheeses displayed antihypertensive activity, but mainly after 8 wk of aging when they were no longer consumable, whereas the Mexican samples did display some angiotensin-converting enzyme inhibitory action after minimal aging.
\end{abstract}

Key words: Hispanic cheese, bioactive peptide, angiotensin-converting enzyme inhibition, antihypertensive activity

\section{Short Communication}

Hypertension, also known as high blood pressure, is a chronic condition that can lead to more severe and deadly illnesses such as stroke and coronary heart disease. Hypertension affects up to $30 \%$ of the adult population in most countries and often goes undiagnosed (Chen et al., 2009). One of the many biological pathways that regulate blood pressure in the human body is the rennin-angiotensin-aldosterone system.

\footnotetext{
Received September 22, 2010.

Accepted February 2, 2011.

${ }^{1}$ Mention of trade names or commercial products in this publication is solely for the purpose of providing specific information and does not imply recommendation or endorsement by the US Department of

${ }^{2}$ Corresponding author: moushumi.paul@ars.usda.gov
} Agriculture.
Angiotensin-converting enzyme (ACE) is a key component in this pathway that catalyzes the conversion of an inactive decapeptide, angiotensin I, to a potent vasoconstrictor, angiotensin II. The enzyme has an additional role in the hydrolysis of bradykinin and kallidin, both compounds with vasodilative activities (Pihlanto et al., 2010). Through these mechanisms, ACE causes blood pressure to increase. Therefore, inhibiting the action of the ACE enzyme can lead to a decrease in blood pressure (Chen et al., 2009).

Some studies have shown a correlation between dairy consumption and lowering of blood pressure (LopezFandino et al., 2006). Subsequent work has targeted and characterized specific milk protein-derived compounds from various dairy products with ACE-inhibitory activity (Korhonen et al., 2006). Many of these have been sequenced and shown to be derived from the enzymatic degradation of milk proteins, mostly caseins, by bacterial proteinases during milk fermentation (Pihlanto et al., 2010). Hence, many ripened cheeses, such as Cheddar (Singh et al., 1997) or aged Gouda (Saito et al., 2000), are sources of bioactive compounds including antihypertensive peptides. Recently, milk fermented using varieties of lactic acid bacteria has been shown to provide antihypertensive peptides derived from $\beta$-casein, as well (Pihlanto et al., 2010).

Interest is increasing in the incorporation of healthpromoting compounds into foods that are readily available to consumers in supermarkets. Several advantages exist to using compounds such as milk protein-derived antihypertensive peptides as food additives. First, because these peptides are milk protein derived, they are already established as safe for human consumption. Many dairy foods on the market already contain these peptides, albeit in relatively small quantities. Second, these peptides are released through proteolytic digest of the parent milk proteins. Although the proteolysis can be carried out by bacterial proteinases during cheesemaking, the intact protein may make it to the gut and be hydrolyzed gastrointestinally, thereby circumventing bioavailability issues with small molecules (LopezFandino et al., 2006). Well-known ACE inhibiting tripeptides VPP and IPP (Nakamura et al., 1995a,b) have also been shown to be resistant to proteolysis in vivo 
(Mizuno et al., 2004), suggesting that these compounds will have long, effective lifetimes within the body and will not be quickly degraded or inactivated.

Understanding the nature of these peptides and their structures and measuring their abilities to inhibit ACE provide information toward better, more effective antihypertensive compounds that can be incorporated into foods. Assessing the natural concentrations of these compounds within items such as ripened cheese provides information as to potential health benefits associated with consuming particular foods. Additionally, researchers have used the information obtained from these types of studies to develop new types of cheeses that contain bioactive peptides with potential health benefits (Ryhanen et al., 2001). Although significant work has been done toward characterizing antihypertensive peptides in many dairy foods, little work has been done to date on identifying them in the increasingly popular Hispanic-style cheeses such as Queso Fresco. According to the National Agricultural Statistical Service, as of 2009, Hispanic-style cheeses are one of the fastest growing cheese varieties in the United States, making up approximately $2 \%$ of total cheese production in this country. This aim of this study was to assess the antihypertensive activity in protein extracts from Queso Fresco made from raw and pasteurized milk obtained from Mexico, as well as in model cheeses developed to mimic the native flavors and taste, made with pasteurized milk without starter cultures in the Dairy and Functional Foods facility at the North Atlantic Area (NAA)-Eastern Regional Research Center (ERRC) of the Agricultural Research Service (ARS) of the USDA.

Model cheeses $\mathrm{A}, \mathrm{B}$, and $\mathrm{C}$ were manufactured in duplicate from raw milk obtained locally. Each batch of cheese was prepared from $180 \mathrm{~kg}$ of milk that had been standardized to $3.5 \%$ (wt/wt) fat, homogenized at 6.9 and $3.4 \mathrm{MPa}$ and then pasteurized at $72^{\circ} \mathrm{C}$ for $15 \mathrm{~s}$. Milk was adjusted to $32^{\circ} \mathrm{C}$ in a cheese vat (Kussel Equipment Co., Watertown, WI), $\mathrm{CaCl}_{2}$ was added to the milk to a final concentration of $0.1 \% \mathrm{wt} / \mathrm{wt}$, and no starter culture was used. Chymosin $(130 \mathrm{~mL}$ per 1,000 L of milk; Chy-Max 73863, Chr. Hansen Inc., Milwaukee, WI) was added to coagulate the milk, and after $30 \mathrm{~min}$ the coagulated curd was cut into $1-\mathrm{cm}$ cubes. The temperature was increased to $39^{\circ} \mathrm{C}$ and the curd was cooked for $30 \mathrm{~min}$. Approximately two-thirds of the whey was drained from the vat, and dry salt (2.3 $\mathrm{kg}$ ) was added in 3 applications and mixed into the slurry for a total of $20 \mathrm{~min}$. The rest of the whey was drained and the curd trenched. When the curd reached $\mathrm{pH}$ 6.3, it was removed from the vat, and chilled to $<21^{\circ} \mathrm{C}$. Chilled curds were finely milled using a Bosch universal 6610UC/01 FD meat grinder (Robert Bosch Hausgeräte GmbH, Dillingen, Germany) or a Waring Pro MG800 meat grinder (Waring Pro, East Windsor, NJ). Milling treatments were (a) no milling and immediately packed into molds; (b) curd was passed through the Bosch meat grinder without a blade; (c) curd was passed through the Bosch meat grinder with a small bore blade (6.3-cm-diameter blade with eighteen 0.7 -cm holes); and (d) curd was passed through the Waring meat grinder with a large bore blade $(6.3 \mathrm{~cm}$ in diameter with five 1.4-cm holes). The curd from each treatment was packed separately into molds and stored overnight at $4^{\circ} \mathrm{C}$. Each cheese was then removed from the mold, divided into 3 blocks, vacuum packaged, and stored at $4^{\circ} \mathrm{C}$. One block from each milling treatment was removed for testing after 1 and 8 wk of storage. Cheeses were designated A1f (i.e., cheese A aged for 1 wk at $\left.4^{\circ} \mathrm{C}\right), \mathrm{A} 1 \mathrm{t}\left(\mathrm{t}=\right.$ aged at $\left.10^{\circ} \mathrm{C}\right), \mathrm{A} 8 \mathrm{f}, \mathrm{A} 8 \mathrm{t}, \mathrm{B} 8 \mathrm{fa}$, $\mathrm{B} 8 \mathrm{fb}, \mathrm{B} 8 \mathrm{fc}, \mathrm{B} 8 \mathrm{fd}, \mathrm{B} 8 \mathrm{t}, \mathrm{C} 8 \mathrm{fa}, \mathrm{C} 8 \mathrm{fb}, \mathrm{C} 8 \mathrm{fc}, \mathrm{C} 8 \mathrm{fd}$, and C8t, where a, b, c, and d refer to milling treatments (D. L. Van Hekken, unpublished work). Mexican Queso Fresco cheeses were obtained from different commercial sources in Sonora, Mexico, and were labeled Mr1 (Mexican raw cheese sample 1), Mr2, Mr3, Mr4, Mp1 (Mexican pasteurized cheese sample 1), and Mp2 (Renye et al., 2008).

For all samples of cheese, water-soluble proteins were extracted using a protocol adapted from multiple cheese protein studies (Gomez-Ruiz et al., 2002; Van Hekken et al., 2004; Silva et al., 2006). Milli-Q water ( $5 \mathrm{~mL}$; Millipore, Billerica, MA) was added to a grated cheese sample (5 g) and the mixture was homogenized by sonication for $6 \mathrm{~min}$. More water was added $(5 \mathrm{~mL})$, and the mixture was further homogenized by sonication for $6 \mathrm{~min}$. The homogenate was stirred at room temperature for $30 \mathrm{~min}$, and then centrifuged at 26,000 $\times g$ for $60 \mathrm{~min}$ at $4^{\circ} \mathrm{C}$. The supernatant was filtered through a Whatman no. 1 filter paper and lyophilized to yield the water-soluble protein extract used in subsequent experiments.

A spectrophotometric assay based on the hydrolysis of the substrate peptide $N$-[3-(2-furyl)acryloyl]-Lphenylalanylglycylglycine (FAPGG) to form the degradation product peptides furylacryloylphenylalanine (FAP) and glycylglycine by ACE was used to assess the ACE inhibitory activity of the water-soluble cheese protein extracts (van der Ven et al., 2002; Vermeirssen et al., 2002; Hou et al., 2003). Assays were performed in duplicate and averages were used for calculations. Protein extract mixtures were used at concentrations of $10 \mathrm{mg} / \mathrm{mL}$. Angiotensin-converting enzyme from rabbit lung and FAPGG were obtained from Sigma-Aldrich (St. Louis, MO). Reaction buffer used for assays was 50 


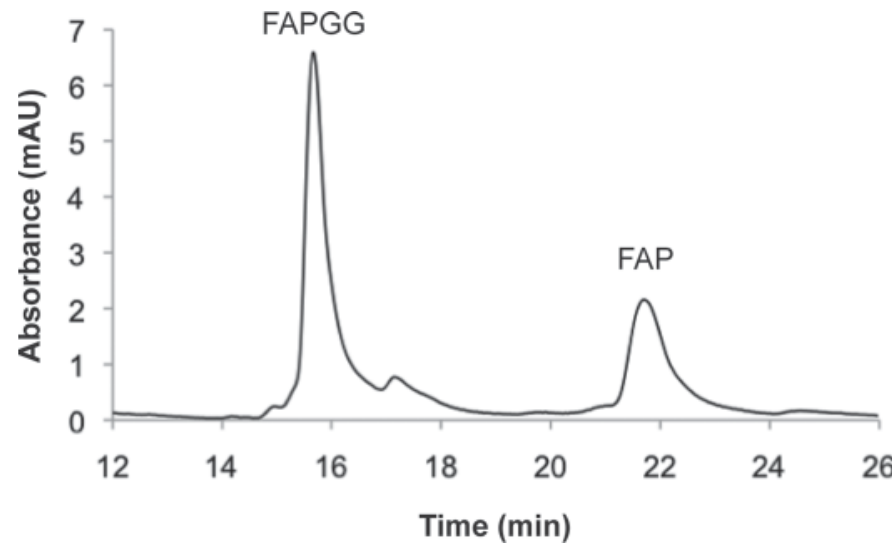

Figure 1. Reversed phase-HPLC C18 chromatograph of $\mathrm{N}$-[3-(2furyl)acryloyl]-L-phenylalanylglycylglycine (FAPGG; substrate) and furylacryloylphenylalanine (FAP; released by hydrolysis of FAPGG) separation as used to assess angiotensin converting enzyme (ACE) inhibitory activity, where ACE inhibition $(\%)=\left[\left(\mathrm{FAP}_{\text {control }}-\mathrm{FAP}_{\text {sample }}\right) /\right.$ $\left.\mathrm{FAP}_{\text {control }}\right] \times 100 . \mathrm{mAU}=$ milli-arbitrary units.

$\mathrm{m} M$ Tris- $\mathrm{HCl}, 300 \mathrm{~m} M \mathrm{NaCl}, \mathrm{pH}$ 8.3; ACE was used at a concentration of $0.0565 \mathrm{U} / \mathrm{mL}$ and FAPGG was used at a concentration of $100 \mu \mathrm{M}$.

Reaction mixtures containing $2.5 \mu \mathrm{L}$ of ACE enzyme, $12.5 \mu \mathrm{L}$ of cheese protein extract, and $20 \mu \mathrm{L}$ of reaction buffer were mixed and preincubated before sampling at $37^{\circ} \mathrm{C}$ for $30 \mathrm{~min}$. To this mixture, $15 \mu \mathrm{L}$ of FAPGG was added to give a final reaction volume of $50 \mu \mathrm{L}$. Samples remained at $37^{\circ} \mathrm{C}$ and aliquots $(10 \mu \mathrm{L})$ were removed at 5 -min intervals; $5 \mu \mathrm{L}$ of $10 \%$ trifluoroacetic acid (TFA) was added to stop the reaction. Liberated FAP was separated from FAPGG by reversed phaseHPLC (Agilent 1200 series HPLC, Agilent Technologies, Santa Clara, CA), monitoring absorbance at 300 $\mathrm{nm}$, using a Vydac C18 column $(5 \mu \mathrm{m}, 4.6 \mathrm{~mm}$ i.d. $\times$ $250 \mathrm{~mm}$ ), eluting isocratically at $27 \%$ of $0.1 \% \mathrm{TFA}$ in water and at $73 \%$ of $0.08 \%$ TFA in acetonitrile at a flow rate of $1 \mathrm{~mL} / \mathrm{min}$ over $25 \mathrm{~min}$, and subsequently quantified (Figure 1). An Agilent photodiode array detector was used as part of the HPLC instrument, and concentration of liberated FAP was calculated based on a calibration curve obtained by plotting various known concentrations of FAP versus absorbance at $300 \mathrm{~nm}$. The ACE inhibitory activity was calculated according to the following formula (where FAP is liberated FAP from hydrolyzed FAPGG):

$$
\begin{gathered}
\text { ACE inhibition }(\%)=\left[\left(\mathrm{FAP}_{\text {control }}-\mathrm{FAP}_{\text {sample }}\right) /\right. \\
\left.\mathrm{FAP}_{\text {control }}\right] \times 100 .
\end{gathered}
$$

Protein extracts from 6 different Queso Fresco varieties obtained from Mexico as well as 12 different
Table 1. Model Queso Fresco inhibition data

\begin{tabular}{lc}
\hline Sample $^{1}$ & $\begin{array}{c}\text { Inhibition } \\
\text { activity (\%) }\end{array}$ \\
\hline No inhibitor & 0 \\
A1f & 22.3 \\
A8f & 95.7 \\
A1t & 43.7 \\
A8t & 85.5 \\
B8fa & 72.2 \\
B8fb & 68.0 \\
B8fc & 80.1 \\
B8fd & 76.5 \\
B8t & 79.7 \\
C8fa & 18.9 \\
C8fb & 46.6 \\
C8fc & 76.0 \\
C8fd & 67.6 \\
C8t & 67.2 \\
\hline
\end{tabular}

${ }^{1} \mathrm{~A}, \mathrm{~B}, \mathrm{C}=$ model Queso Fresco cheeses; 1 and $8=$ aged for 1 and $8 \mathrm{wk}$ respectively; $\mathrm{f}$ and $\mathrm{t}=$ aged at $4^{\circ} \mathrm{C}$ and $10^{\circ} \mathrm{C}$, respectively; a, b, c, and $\mathrm{d}=$ milling treatments: $\mathrm{a}=$ no milling and immediately packed into molds; $\mathrm{b}=$ curd was passed through a Bosch meat grinder without a blade; $\mathrm{c}=$ curd was passed through the Bosch meat grinder with a small-bore blade (6.3-cm-diameter blade with eighteen $0.7-\mathrm{cm}$ holes); and $\mathrm{d}=$ curd was passed through the Waring meat grinder with a large-bore blade $(6.3 \mathrm{~cm}$ in diameter with five $1.4-\mathrm{cm}$ holes).

model cheeses made without using starter cultures were assayed for antihypertensive activity. Results for the model cheeses are presented in Table 1. Protein extracts from A1f (cheese sample A stored at $4^{\circ} \mathrm{C}$ for $1 \mathrm{wk}$ ) showed $22 \%$ inhibition of the ACE activity, whereas the same sample after 8 wk of aging (A8f) showed $95.7 \%$ inhibition. Sample A stored at $10^{\circ} \mathrm{C}$ showed a similar increase in inhibition activity, from $43.7 \%$ after $1 \mathrm{wk}$ of aging (A1t) to $85.5 \%$ inhibition after $8 \mathrm{wk}$ (A8t). Because these cheeses were not made using starter cultures, the observed increase in inhibition activity can be attributed to spoilage bacteria that could provide the enzymes needed to proteolyze the proteins to generate the ACE inhibitory compounds. This effect was universally observed with all of the $\mathrm{B}$ and $\mathrm{C}$ model cheeses as well, with 1-wk samples showing some slight ACE inhibition (data not shown) and 8-wk samples showing a significant increase in inhibition, regardless of storage temperature. In all cases (Table 1), with the exception of the $\mathrm{C} 8 \mathrm{~b}$ sample, the model cheeses displayed at least $50 \%$ inhibition after 8 wk of aging, presumably due to protein degradation by spoilage bacteria.

In contrast, the Mexican cheeses showed significant ACE inhibitory activity after $1 \mathrm{wk}$ of storage (Table 2). The original A and B samples, corresponding to data labeled Mr1, Mr2, Mr4, and Mp1, all exhibited 87 to $93 \%$ ACE inhibition compared with assays conducted with the enzyme alone. The Mr3 and Mp2 samples showed some inhibition activity ( 36 and $51 \%$, respectively), but it was not as high as that seen in the other samples and 
Table 2. Mexican Queso Fresco inhibition data

\begin{tabular}{lc}
\hline Sample $^{1}$ & $\begin{array}{c}\text { Inhibition } \\
\text { activity }(\%)\end{array}$ \\
\hline Mr1 & 89.8 \\
Mr2 & 87.2 \\
Mr3 & 36.3 \\
Mr4 & 92.1 \\
Mp1 & 93.1 \\
Mp2 & 50.8 \\
\hline
\end{tabular}

${ }^{1}$ Mexican raw milk cheeses (Mr1, Mr2, Mr3, and Mr4) and Mexican pasteurized milk cheeses (Mp1 and Mp2) assayed without aging.

was more comparable to the activities of the protein extracts obtained from the model cheeses before aging. The overall bacterial content of these cheeses has been studied (Renye et al., 2008) and revealed that although the Mr1, Mr2, Mr3, and Mr4 samples were made from raw milk and Mp1 and Mp2 were made from pasteurized milk, the overall contamination in all samples with non-food-grade bacteria was very high. Even though the raw milk cheeses contained higher populations of bacteria, leading to the overall increased ACE inhibitory activity observed with these cheeses, the Mp1 and Mp2 cheeses were also exposed to contaminating bacteria, which would likely affect the protein breakdown in these cheeses, causing increased activity as well. Assessing the activity of protein extracts obtained from the Mexican cheese samples after aging has not yet been performed, but may show an increase in the activity of the Mr3 and Mp2 samples, as seen with the model cheeses.

A long list of cheeses, including Gouda and Cheddar, have previously been shown to exhibit some antihypertensive activity, and our results indicate that Queso Fresco could be added to the list. Numerous Spanish cheeses such as Manchego, Roncal, and Mahón have been reported to exhibit inhibitory activity, with Cabrales cheese, made without a starter culture, having the highest measured activity of $76.1 \%$ (Gomez-Ruiz et al., 2006). Studies on the ripening of Swiss cheese varieties such as Emmentaler and Le Gruyère showed that ACE inhibitory activities in these cheeses were related to elevated concentrations of 2 known ACE-inhibiting peptides, VPP and IPP, which could be associated with the presence of Lactobacillus helveticus strains in the starter cultures (Meyer et al., 2009). More recently, ACE inhibitory activity was identified in water-soluble extracts from the Italian cheese Asiago d'allevo (Lignitto et al., 2010).

Pooling this type of information has led to the development of novel cheeses with potential health benefits by manipulating ripening times and bacterial strains used as starter cultures (Ryhanen et al., 2001). Future work involving the isolation and characterization of the ACE-inhibitory compounds within the Quesos Frescos in the present study will add to the current available data on cheese production. This information, along with a more comprehensive understanding of the bacterial strains, if any, responsible for the production of small bioactive peptides in the cheese matrices may eventually lead to cheeses that can lower blood pressure in American consumers.

Protein extracts from a variety of Mexican and model Queso Frescos were assayed for antihypertensive activity. Although the model cheeses displayed some ACE inhibitory activity before aging, significant increases were observed after $8 \mathrm{wk}$ of storage. Presumably, this is due to the presence of proteases associated with spoilage bacteria that grow during the aging period. The Mexican Queso Frescos were made from raw and pasteurized milk, but all were contaminated to some extent by non-food-grade bacterial species. The protein extracts from these samples showed elevated levels of ACE inhibition without aging, which implies that the inhibitory compounds are either already present in the milk used for cheese-making or are generated during cheese-making, most likely as a result of milk protein breakdown leading to smaller antihypertensive peptides. Further investigations will more thoroughly examine which bacteria are needed to generate the antihypertensive peptides, as well as fully characterize those peptides responsible for this activity.

\section{ACKNOWLEDGMENTS}

The authors acknowledge George Somkuti and Dennis Steinberg (Dairy and Functional Foods Research Unit, USDA-ARS-NAA-ERRC, Wyndmoor, PA) for assistance with the ACE inhibition assay conditions, and Raymond Kwoczak, Latasha Leggett, and Danielle Tillman (Dairy and Functional Foods Research Unit, USDA-ARS-NAA-ERRC, Wyndmoor, PA) for their assistance in cheese making.

\section{REFERENCES}

Chen, Z. Y., C. Peng, R. Jiao, Y. M. Wong, N. Yang, and Y. Huang. 2009. Anti-hypertensive nutraceuticals and functional foods. J. Agric. Food Chem. 57:4485-4499.

Gomez-Ruiz, J. A., M. Ramos, and I. Recio. 2002. Angiotensin-converting enzyme-inhibitory peptides in Manchego cheeses manufactured with different starter cultures. Int. Dairy J. 12:697-706.

Gomez-Ruiz, J. A., G. Taborda, L. Amigo, I. Recio, and M. Ramos. 2006. Identification of ACE-inhibitory peptides in different Spanish cheeses by tandem mass spectrometry. Eur. Food Res. Technol. 223:595-601.

Hou, W. C., H. J. Chen, and Y. H. Lin. 2003. Antioxidant peptides with angiotensin converting enzyme inhibitory activities and applications for angiotensin converting enzyme purification. J. Agric. Food Chem. 51:1706-1709.

Korhonen, H., and A. Pihlanto. 2006. Bioactive peptides: Production and functionality. Int. Dairy J. 16:945-960. 
Lignitto, L., V. Cavatorta, S. Balzan, G. Gabai, G. Galaverna, E. Novelli, S. Sforza, and S. Segato. 2010. Angiotensin-converting enzyme inhibitory activity of water-soluble extracts of Asiago d'allevo cheese. Int. Dairy J. 20:11-17.

Lopez-Fandino, R., J. Otte, and J. van Camp. 2006. Physiological, chemical and technological aspects of milk-protein-derived peptides with antihypertensive and ACE-inhibitory activity. Int. Dairy J. 16:1277-1293.

Meyer, J., U. Butikofer, B. Walther, D. Wechsler, and R. Sieber. 2009 Hot topic: Changes in angiotensin-converting enzyme inhibition and concentrations of the tripeptides Val-Pro-Pro and Ile-Pro-Pro during ripening of different Swiss cheese varieties. J. Dairy Sci. $92: 826-836$.

Mizuno, S., S. Nishimura, K. Matsuura, T. Gotou, and N. Yamamoto. 2004. Release of short and proline-rich antihypertensive peptides from casein hydrolysate with an Aspergillus oryzae protease. J. Dairy Sci. 87:3183-3188.

Nakamura, Y., N. Yamamoto, K. Sakai, A. Okubo, S. Yamazaki, and T. Takano. 1995a. Purification and characterization of angiotensin I-converting enzyme inhibitors from sour milk. J. Dairy Sci. 78:777-783.

Nakamura, Y., N. Yamamoto, K. Sakai, and T. Takano. 1995b. Antihypertensive effect of sour milk and peptides isolated from it that are inhibitors to angiotensin I-converting enzyme. J. Dairy Sci. $78: 1253-1257$.

Pihlanto, A., T. Virtanen, and H. Korhonen. 2010. Angiotensin I converting enzyme (ACE) inhibitory activity and antihypertensive effect of fermented milk. Int. Dairy J. 20:3-10.
Renye, J. A., G. A. Somkuti, B. Vallejo-Cordoba, D. L. Van Hekken, and A. F. Gonzalez-Cordova. 2008. Characterization of the microflora isolted from queso fresco made from raw and pasteurized milk. J. Food Saf. 28:59-75

Ryhanen, E. L., A. Pihlanto-Leppala, and E. Pahkala. 2001. A new type of ripened, low-fat cheese with bioactive properties. Int Dairy J. 11:441-447.

Saito, T., T. Nakamura, H. Kitazawa, Y. Kawai, and T. Itoh. 2000. Isolation and structural analysis of antihypertensive peptides that exist naturally in Gouda cheese. J. Dairy Sci. 83:1434-1440.

Silva, S. V., A. Pihlanto, and F. X. Malcata. 2006. Bioactive peptides in ovine and caprine cheeselike systems prepared with proteases from Cynara cardunculus. J. Dairy Sci. 89:3336-3344.

Singh, T. K., P. F. Fox, and A. Healy. 1997. Isolation and identification of further peptides in the diafiltration retentate of the watersoluble fraction of Cheddar cheese. J. Dairy Res. 64:433-443.

van der Ven, C., H. Gruppen, D. B. A. de Bont, and A. G. J. Voragen. 2002. Optimization of the angiotensin converting enzyme inhibition by why protein hydrolysates using response surface methodology. Int. Dairy J. 12:813-820.

Van Hekken, D. L., M. H. Tunick, and Y. W. Park. 2004. Rheological and proteolytic properties of Monterey Jack goat's milk cheese during aging. J. Agric. Food Chem. 52:5372-5377.

Vermeirssen, V., J. Van Camp, and W. Verstraete. 2002. Optimisation and validation of an angiotensin-converting enzyme inhibition assay for the screening of bioactive peptides. J. Biochem. Biophys. Methods 51:75-87. 